\title{
"Demand of HR-competency in Ukraine: changes and challenges at the labor market under pandemic COVID-19"
}

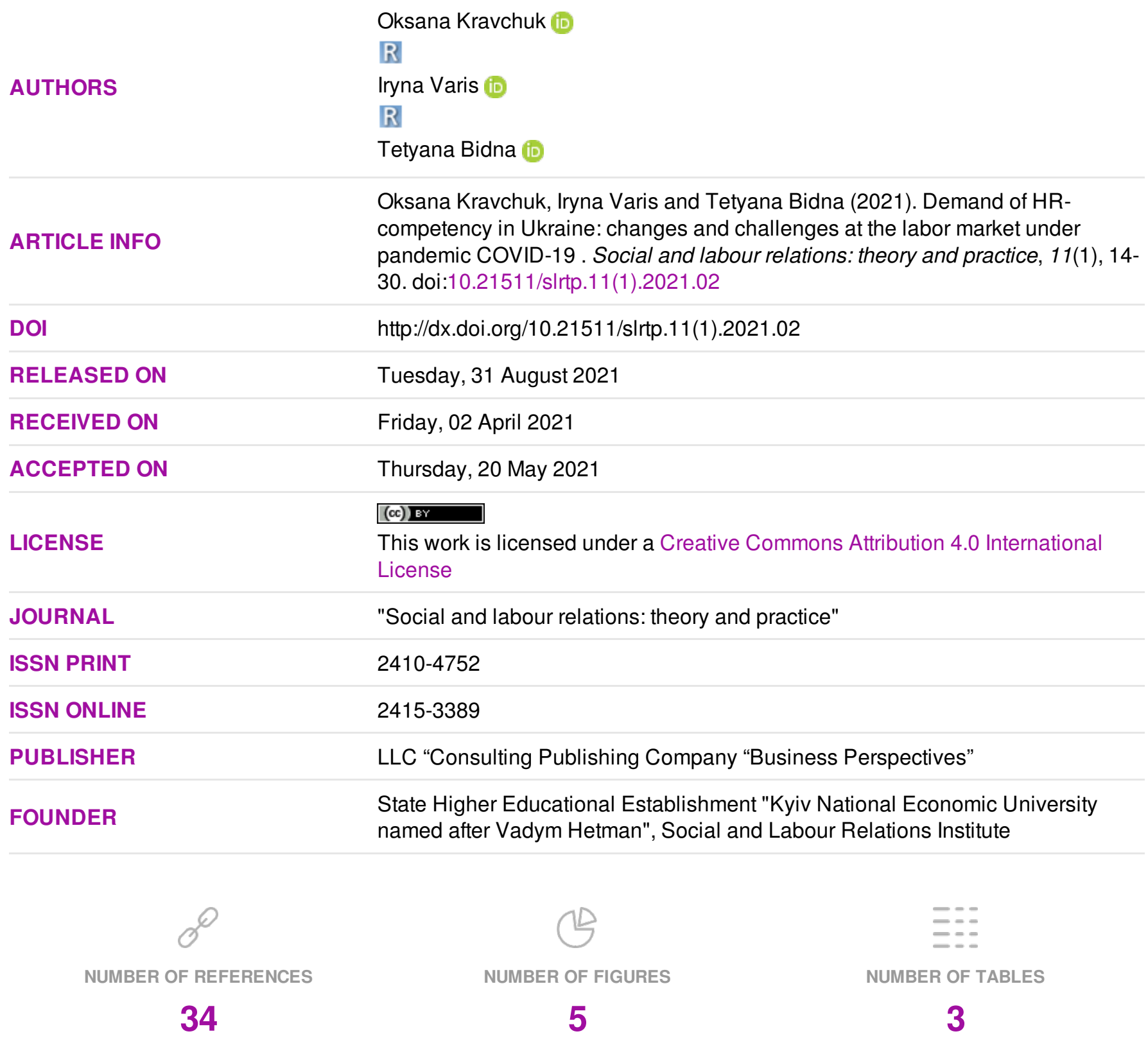

(c) The author(s) 2021. This publication is an open access article. 


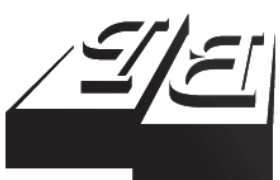

BUSINESS PERSPECTIVES

Publisher

LLC "CPC "Business Perspectives" Hryhorii Skovoroda lane, 10, Sumy, 40022, Ukraine www.businessperspectives.org

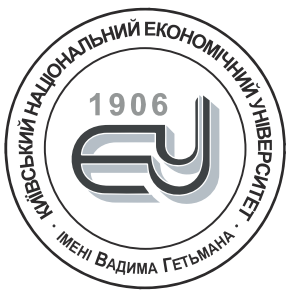

\section{HETMAN KNEU}

Founder

State Higher Educational Establishment "Kyiv National Economic University named after Vadym Hetman",

Prospect Peremogy, 54/1

Kyiv, 03057, Ukraine

https://kneu.edu.ua/

Received on: 2nd of April, 2021 Accepted on: 20th of May, 2021 Published on: 31th of August, 2021

() Oksana Kravchuk, Iryna Varis, Tetyana Bidna, 2021

Oksana Kravchuk, Ph.D. in Economics, Associate Professor Kyiv National Economic University named after Vadym Hetman, Ukraine.

Iryna Varis, Ph.D. in Economics, Associate Professor, Kyiv National Economic University named after Vadym Hetman, Ukraine.

Tetyana Bidna, Higher Education Seeker, Kyiv National Economic University named after Vadym Hetman, Ukraine.

\section{(c) (i)}

This is an Open Access article, distributed under the terms of the Creative Commons Attribution 4.0 International license, which permits unrestricted re-use, distribution, and reproduction in any medium, provided the original work is properly cited.
DEMAND OF HR-COMPETENCY IN UKRAINE: CHANGES AND CHALLENGES AT THE LABOR MARKET UNDER
PANDEMIC COVID-19

\begin{abstract}
The experience of the last year of business operation has highlighted the need to find new ways and approaches to managing people, through the crisis caused by the COVID-19 coronavirus pandemic. New socio-economic reality, digitalization and socialization are transforming the people management processes of, which, in turn, changes the modern requirements for HR competencies.

The article's purpose is to form a model of personnel manager competencies by clusters of general and professional competencies based on the implementation of best international experience in forming and developing HR competencies models and considering demand trends in the Ukrainian labor market in the segment «HR Management» in modern realities.

To produce results, the following methods were used: abstract-logical to generalize the scientific literature; monographic and analogies to summarize the international experience of forming HRcompetencies models; empirical for the analysis of trends in the formation of demand for HRcompetencies in the Ukrainian labor market; modeling to develop a modern HR competencies model for Ukraine; generalizations to draw conclusions. The generalization of the current state of scientific research and international experience in modeling HR-competencies allowed to structure the current HR-competencies of SHRM, HRCI, CIPD and to develop proposals for their implementation in Ukrainian HR-practice. The analysis of the demand for HR-competence in Ukraine allowed to select the most popular of them by general, managerial, and special clusters; to identify the frequency of demand for HR-competences and calculate their weight level. On this basis, the structure of demand in the labor market of Ukraine in the segment of «HR-Management» was generalized. The influence of changes and challenges of the organization's activity during the pandemic COVID-19 on the transformation of the roles of people management and the current HR competencies model in Ukraine is substantiated. Prospective directions of using the model for professional standard development, educational services improvement, and development of the national system of HR-certification for making better the quality and performance of the human resource management function in Ukraine are proposed.
\end{abstract}

\section{Keywords}

JEL Classification personnel management, people management; HR professional competency; competency model, demand for HR competencies, HR manager

M12, J24, J44
О. I. Кравчук (Україна), I. О. Варіс (Україна), Т. О. Бідна (Україна)

\section{ПОПИТ НА НR-КОМПЕТЕНТНОСТІ В УКРАЇНІ: ЗМІНИ ТА ВИКЛИКИ НА РИНКУ ПРАЦІ ПІД ЧАС ПАНДЕМІЇ COVID-19}

\footnotetext{
Анотація

Досвід останнього року функціонування бізнесу актуалізував необхідність пошуку нових способів та підходів до управління людьми, зокрема через кризу, спричинену пандемією коронавірусу COVID-19. Нова соціоекономічна реальність, цифровізація та соціалізація трансформують процеси менеджменту персоналу, що, своєю чергою, змінює сучасні вимоги до HR-компетентностей. Мета статті полягає в формуванні моделі компетентностей менеджера з персоналу за кластерами загальних та професійних компетентностей на основі імплементації передового міжнародного досвіду формування та розвитку моделей $\mathrm{HR}$ компетентностей та врахування тенденцій попиту на українському ринку праці у сегменті
} 
«Менеджмент персоналу» в сучасних реаліях. Для продукування результатів було використано методи: абстрактно-логічні для узагальнення наукової літератури; монографічний та аналогії для узагальнення міжнародного досвіду формування моделей HR-компетентностей; емпіричні для аналізу тенденцій формування попиту на HR-компетентності на ринку праці України; моделювання для розроблення актуальної моделі HR-компетентностей для України; узагальнення для продукування висновків. Узагальнення сучасного стану наукових досліджень та міжнародного досвіду моделювання НR-компетентностей дозволили структурувати актуальні HR-компетентності SHRM, HRCI, CIPD та розробити пропозиції щодо їх імплементації в українську HR-практику. Аналіз попиту на HR-компетентності в Україні дозволив виділити найзатребуваніші з них за кластерами: загальні, управлінські, спеціальні; виявити частоту попиту на HR-компетентності та розрахувати рівень вагомість кожної з них. На цій основі узагальнено структуру попиту на ринку праці України в сегменті «Менеджменту персоналу». Обгрунтовано вплив змін та викликів діяльності організації під час пандемії COVID-19 на трансформацію ролей менеджменту персоналу та моделі актуальних HR-компетентностей в Україні. Запропоновано перспективні напрямки використання моделі НR-компетентностей для розроблення професійних стандартів, вдосконалення освітніх послуг та розроблення національної системи НR-сертифікації задля підвищення якості кадрового забезпечення реалізації функції менеджменту персоналу в Україні.

Ключові слова

менеджмент персоналу, управління людьми; професійні HR компетентності, модель компетентностей, попит на HR компетентності

Класифікація JEL

M12, J24, J44

\section{ВСТУП}

Функціонування сучасної організації у швидко змінюваних непередбачуваних умовах постійно ставить іiі перед необхідністю, з одного боку, збереження своїх позицій на ринку та виживання у конкурентній боротьбі, а 3 іншого - протистояння викликам та загрозам діяльності, зумовлених пандемією коронавірусу COVID-19. Досвід останнього року підтвердив помилковість зосередження бізнесу виключно на матеріальних активах для виживання та розвитку, а також актуалізував необхідність пошуку нових способів та підходів до управління основним нематеріальним активом - інтелектуальним капіталом організації, зокрема: організації та утримання персоналу під час частково чи повністю дистанційної роботи, нові способи реалізації процесів добору, адаптації, мотивації, навчання та розвитку персоналу в нових умовах. Цей виклик стрімко увірвався в практику менеджменту персоналу і через кризу, спричинену пандемією коронавірусу COVID-19. Нова нормальна реальність суттєво змінює процеси менеджменту персоналу, що своєю чергою трансформує вимоги до компетентностей сучасних менеджерів 3 персоналу, які мають бути здатні їх реалізовувати у нових умовах. Перегляду потребуюсь наявні в міжнародній практиці моделі компетентностей в сфері менеджменту персоналу з точки зору їх здатності забезпечувати виконання «нових нормальних» процесів менеджменту персоналу в сучасній організації. Крім цього, потрібно адаптувати ці практики до особливостей розвитку сфери професійної діяльності «Менеджмент персоналу» в Україні, враховуючи основні тенденції їі розвитку для усунення поширених проблем українських менеджерів з персоналу при визначенні функціональної спрямованості їх діяльності, розподілу ролей та закріплення за ними відповідного переліку компетентностей та рівнів їх розвитку. Сучасний стан дослідження даної проблематики характеризується недостатньої увагою теоретико - методичним та прикладним аспектам моделювання компетентностей менеджера 3 персоналу в Україні. Відсутній єдиний підхід і бачення моделі компетентностей менеджера з персоналу, що спричинює проблеми із розробленням профілів посад, вимог до загальних та професійних компетентностей. Паралельно не можна нівелювати тенденції ринку праці в сегменті «Менеджмент персоналу» в Україні, зокрема, попит на конкретні навички та їх пропозицію, а також особливості їх зміни під час пандемії коронавірусу COVID-19. Саме необхідність визначення «нової нормальної» моделі компетентностей менеджера з персоналу, які, одночасно, відповідатиме міжнародним стандартам 3 управління персоналу та відображатиме українські реалії розвитку цієї сфери професійної діяльності, обгрунтовує актуальність дослідження.

\section{1. ЛІТЕРАТУРНИЙ ОГЛЯА}

Роль менеджерів з персоналу з часом стає не абияк помітною в організації. Обгрунтуванню їх вагомого впливу на розвиток організації та бізнесу в цілому присвячені останні роботи Ульріха, Грочовські [29; 31]. Зростаючий вплив та тенденції розвитку компетентності в сфері управління людьми в організації обумовлений рядомчинників, аналізуякихпротягомостанньоїдекадипроводилив своїхнауковихроботах Алонзо [1], Бернс, Сміт та Ульріх [4; 32]. Формування та розвиток потенціалу сфери НR супроводжується невпинним впровадженням інноваційних підходів до розроблення моделі компетеностей менеджерів 3 
персоналу та запровадження комплексного підходу до управління їх компетентностями в цілому на рівні організації, яким приділено уваги у роботах Лоу [16]. Питання розвитку сфери стратегічного менеджменту персоналу та його ролі у організаційних змінах впродовж останніх років відображені у працях Сторі, Райта та Ульріха [28], Дас-Гупта [7], Ходжеса та Кребтрі [11] та багатьох інших, де автори узагальнюють основні унікальні дані про виклики та можливості, з якими стикається практика менеджменту персоналу в контексті організаційних змін, при цьому розглядаючи сучасні теоретичні перспективи та рамки, можливість їх застосування в реальних умовах в контексті споріднення з суміжними дисциплінами. Беккер та МакКормік [2], Прабаваті та Аоктаріянда концентрують увагу саме на компетентносній моделі менеджменту персоналу при якій компетентність описується як ряд атрибутів через основні стратегії, які містять в собі організаційне сканування, стратегічне планування, профілювання компетентностей, аналіз розриву компетентностей та розвиток компетентності [23]. Мангалесваран визначає компетентності менеджера з персоналу як основу його ефективної діяльності та робить висновки щодо їх вирішального значення не тільки для управління людськими ресурсами, але й для вирішення більш глобальних проблем на рівні всієї організації [18]. Маккартні та Мерфі підкреслюють важливість розробки сучасної моделі компетентності для менеджера з персоналу та застосовують практичний аналіз ринку п’яти країн для розробки власної моделі компетентності, внаслідок чого отримують універсальні шість компетенцій, які необхідні HR-аналітикам [19]. В свою чергу, Берсін [3] та Ульріх [30] характеризуючи сучасний етап розвитку, зазначають, що швидкоплинність вимог до HR-компетентностей, стрімка їх трансформація, багато в чому пояснюється цифровізацією менеджменту персоналу, модернізацією НR-технологій та пристосуванням діяльності організації до нових умов іiї реалізації під час пандемії коронавірусу COVID-19 та у постпандемічний період.

Ваговий внесок у формування моделі компетентностей менеджера з персоналу у світовому масштабі зробили міжнародні організації. Зокрема, SHRM - Міжнародне товариство з управління людськими ресурсами (з англ. Society for Human Resource Management, скор. SHRM) - розробили методологічну основу для впорядкування моделі компетентностей для професії управління персоналом [26]. Декількома роками раніше, CIPD, команда вчених Королівського інституту персоналу та розвитку (з англ. Chartered Institute of Personnel Development, cкор. CIPD), оприлюднили власний підхід до формування сучасного концептуального бачення оптимального набору компетентностей для процесії менеджера з персоналу [6]. Згідно Мегінлі, постійну роботу з визначення актуальних професійних компетеностей для управління людьми в організації здійснює та Інституту сертифікації персоналу (з англ. HR Certification Institute, cкор. HRCI) разом з дослідницькою групою RBL Group [20]. Усі розроблені зазначеними вище організаціями моделі HR компетентностей покладено в основу найвідоміших нині сертифікаційних програм в сфері менеджменту персоналу.

Напрацювання української наукової спільноти в даному напрямі можна репрезентувати окремими роботами, які розглядають різні аспекти формування компетентності менеджерів з персоналу в контексті цифровізації та формування нової соціально-економічної реальності, зокрема, це дослідження Колота [12], Лопушняк [17], Петрової [22], Василик [33], Столярук [27], а також окремим питанням формування професійної компетентності менеджера з персоналу присвячено попередні наукових доробок авторів даної статті $[13-15 ; 21 ; 34]$. Проте попри глибокий рівень досліджень теоретико-методичних аспектів формування компетентності менеджера з персоналу, систематизації та розроблення профілю окремих компетентностей в цій сфері, варто зазначити, що комплексний підхід до формування моделі HRкомпетентностей, який би охоплював як загальні так і професійні компетентності та базувався одночасно на аналізі міжнародного досвіду, з одного боку, та попиту на ринку праці у сегменті «Менеджменту персоналу», з іншого, залишився поза межами безпосередньої уваги вчених.

\section{2. МЕТА ДОСЛІДЖЕННЯ}

Мета полягає в формуванні моделі компетентностей менеджера з персоналу, яка включала 6 як загальні, так і спеціальні (професійні) компетентності, та базувалася одночасно на аналізі міжнародного досвіду формування та розвитку моделей компетентностей в сфері управління людьми, з одного боку, та тенденціях попиту на українському ринку праці у сегменті «Менеджменту персоналу» в сучасних реаліях з іншого. 


\section{3. МЕТОДОЛОГІЯ}

Під час проведення дослідження для продукування основних результатів було використано наступний методичний інструментарій: абстрактно-логічні методи для аналізу та узагальнення наукової літератури; монографічний метод для узагальнення сучасного міжнародного досвіду формування моделей HR компетентностей; емпіричні методи - спостереження та збору даних для дослідження тенденцій формування попиту на HR компетентності на ринку праці України в сегменті «Менеджмент персоналу»; метод аналогії для включення сучасного міжнародного досвіду при формуванні моделі HR компетентностей; метод моделювання для розроблення моделі HR компетентностей; метод узагальнення для підбиття підсумків та продукування висновків.

\section{4. РЕЗУЛЬТАТИ}

В сучасних умовах роль менеджменту персоналу в управлінні організаціями стрімко трансформується та зростає. Нині дана сфера посідає одне з головних місць в управлінні організацією, особливо у великих за розміром компаніях. Ефективність та продуктивність персоналу, підвищення його потенціалу напряму залежать від правильно обраної політики і стратегії менеджменту персоналу, оптимально спроектованих, спланованих і реалізованих програм і заходів їх реалізації. Крім цього, сучасні компанії змушені функціонувати в умовах невизначеності та постійної зміни впливу зовнішніх і внутрішніх чинників. Система менеджменту персоналу має вчасно та оперативно реагувати на ці виклики, а тому має оперативно трансформувати процеси, заходи, програми для того, щоб забезпечувати організацію необхідним персоналом відповідно якості. Все перераховане вище змінює вимоги до сучасного менеджера з персоналу, трансформує модель його компетентностей актуалізуючи нові знання, вміння і навички. Тенденції розвитку управлінських компетентностей в цілому впродовж останніх десятиліть виокремлювали окремі аспекти навичок, які потрібні для результативної праці фахівцеві з управління персоналом. Однак універсальної моделі компетентностей, яка 6 визначала знання, вмінні, навички та поведінку, які необхідні сучасному менеджеру з персоналу аби відповідати всім викликам та виконувати усі завдання, які ставить перед ним практика діяльності в українських реаліях, не було сформовано.

Однозначним залишається той факт, що фахівці в сфері менеджменту персоналу мають бути високо кваліфікованими, проте за яким переліком знань, умінь та навичок має підтверджуватись відповідний рівень кваліфікації в сфері менеджменту персоналу в Україні не визначено. Тому топ-менеджмент сучасних компаній, зацікавлений у зростанні ефективності роботи з персоналом, потребує не тільки перелік загальних компетентностей менеджера 3 персоналу, але й професійних, їх деталізацію за дескрипторами, механізми оцінювання та розвитку.

Аналіз сучасного розуміння та підходів до визначення понять «компетентність» [5] та «модель компетентностей» [9], дають нам підстави стверджувати, що компетентність менеджера з персоналу має включати деталізацію сукупності актуальних для сучасної практики реалізації професійної діяльності знань, умінь, навичок та особистісних характеристик, які пов'язані з виконанням значного аспекту практики професії. На основі визначення та опису актуальних для ринку праці України компетентностей менеджера $з$ персоналу виникає можливість формування сучасної моделі компетентностей, яка включатиме усю сукупність компетентностей, які визначають ефективність роботи в сфері менеджменту персоналу. При цьому особливої уваги потрібно приділити: формуванню актуального рівня знань для менеджера $з$ персоналу, тобто визначення необхідних фактів і цифр, концепцій та гіпотез, які безпосередньо забезпечують пізнання сфери менеджменту персоналу та відповідають сучасному рівню розвитку науки щодо управління людьми в організації; розвиткові навичок, які обумовлюють формування здатності менеджера з персоналу використовувати отримані раніше знання для реалізації актуальних для практики процесів менеджменту персоналу задля отримання високого рівня ефективності та результативності праці; стимулювання формування ставлення через активацію тактики сприйняття і узгодженості щодо людини, ситуації або ж концепцій, які схиляють до певних реакцій або дій. Таким чином, можна зробити висновок, що актуальні компетентності менеджера з персоналу 
мають відображати моделі поведінки, які відображають досконалість у виконанні в межах конкретних бізнес-процесів менеджменту персоналу. У випадку застосування моделі компетентностей, вона являє собою набір загальних та професійних компетентностей, які потрібні фахівцеві для здійснення основних процедур і операцій в рамках зазначених бізнес-процесів.

Визначення актуальних компетентностей для менеджера з персоналу, які необхідно включити у модель компетентностей, має відбуватися на основі одночасно: імплементації міжнародного досвіду в даному напрямі та аналізу вимог українського ринку праці в сегменту «Менеджмент персоналу».

В контексті реалізації першої частини - особливої уваги заслуговують результати дослідження міжнародних моделей компетентностей в сфері менеджменту персоналу, проведеного Притулою [24], який на основі порівняння міжнародних підходів презентував модель компетентностей HR, в яку входить 40 ключових HR посад i, відповідно, така ж кількість компетентностей, яким кожен 3 них має володіти. Експериментальні дослідження автора, які відбувалися протягом року, були основані на найпоширеніших посадах, в тому числі в сфері менеджменту персоналу, а їх результати мають інноваційних характер через виділення базового, помірного, глибокого та експертного рівнів володіння компетентностями та одночасного групування компетентностей в межах кожного рівня за загальними (soft skills) та професійними (hard skills) компетентностями, які були втілені у карті компетентностей фахівців в сфері менеджменту персоналу. Незважаючи на інноваційний характер, унікальність та можливість прикладного використання даної карти компетентностей менеджера 3 персоналу, аналіз iї можливостей показав складнощі роботи з нею через окремі недоліки. Перш за все - це ускладнене розуміння масиву даних. Також дефект міститься в якості опису, яким власне автор задоволений лише на $80 \%$, оскільки він дійсно складний для сприйняття. Щодо переваг, то тут можна виокремити унікальну можливість не тільки переглядати компетентності, а й будувати власний план розвитку для менеджера з персоналу при переході між рівнями і посадами. Адже за підсумками можна розглянути такі дані, як: загальний рівень розвитку загальних та професійних компетентностей, рівень розвитку кожної з 40 компетентностей та загальний рівень. Внаслідок фахівець в сфері менеджменту персоналу матиме змогу оцінити глибину своїх знань та в дійсності оцінити рівень, на якому він знаходиться.

Задля повного розуміння актуальних компетентностей менеджера з персоналу у світі тенденції розвитку міжнародної практики моделювання HR компетентностей потребують глибокого аналізу та дослідження. Це важливо для майбутнього розуміння щодо доцільності впровадження зазначених моделей в практику діяльності українських компаній та встановлення рівня відповідності їм тих вимог до менеджера 3 персоналу, які сформувались на українському ринку праці.

Першою має бути проаналізована розроблена SHRM [26] модель HR компетентностей (з англ. The SHRM Body Of Competency and Knowledg, скор. SHRM BoCK). SHRM BoCK описує поведінкові компетентності та знання, які потрібні HR-фахівцям для ефективної роботи, яка об’єднує вісім поведінкових компетенцій у три кластери: лідерство (лідерство та навігація та етична практика), міжособистісні комунікації (управління відносинами, комунікація, глобальна та культурна ефективність) та бізнес (бізнес-хватка, консалтинг, критична оцінка). Крім того, SHRM BoCK організовує 15 сфер знань 3 менеджменту персоналу, які включені у технічну компетентність HR-експертизу у трьох кластерах: люди (стратегічне планування персоналу, отримання талантів, залучення та утримання працівників, навчання та розвиток, загальна винагорода), організація (структура HR-функції, організаційна ефективність та розвиток, управління робочою силою, соціально-трудові відносини, управління технологіями) та робоче місце (HR у глобальному контексті, різноманітність та інклюзія, управління ризиками, корпоративна соціальна відповідальність, трудове законодавство).

Наступна модель компетентностей, яка обов’язково має бути проаналізована при дослідження міжнародної практики моделювання HR компетентностей - це модель компетентностей від CIPD [6], яка спроектована на основі виділення наступних кластерів компетеностей: базових, базових поведінкових та спеціальних професійних компетентностей. До базових, або загальних компетентностей в Новій професійній карті CIPD віднесені шість необхідних ключових, або основних, на основі яких проводяться 
зміни, створюється цінність і виявляється позитивний вплив і на бізнес в цілому, і на соціально-трудові відносини, зокрема: практика роботи з людьми, культура і поведінка, бізнес оточення, аналітика та створення цінності, використання цифрових технологій, зміни. CIPD вважає, що базові компетентності необхідні для менеджера з персоналу - незалежно від ролі, спеціалізації або галузі, в якій веде свою діяльність їх компанія, - і включають в себе все необхідне для успішної професійної діяльності. Нова модель компетентностей CIPD пропонує HR професіоналам міцну основу для ефективного прийняття рішень в рамках виконання посадових обов'язків. Для цього виділено вісім поведінкових компетентностей, що дозволяють HR професіоналам створювати цінність для працівників, компаній, суспільства і своєї професії з управління людьми: практика, заснована на етиці; професійна сміливість і вплив; розуміння цінності людей; забезпечення соціо-культурного розмаїття; націленість на створення цінності; пристрасть до навчання; фокус на розумінні; ситуаційне прийняття рішень. Основні моделі поведінки описують в загальних рисах, як необхідно діяти, щоб бути ефективним HR професіоналом в сучасному невизначеному світі соціально-трудових відносин. Нова карта професій CIPD надає професії управління людьми найсильніший фундамент для ефективного прийняття рішень. Для цього виділено дев'ять спеціальних компетентностей: організаційний розвиток та дизайн; добір персоналу; управління талантами; навчання та розвиток; досвід працівників; трудові відносини; винагорода; соціо-культурне розмаїття та інклюзія; HR-аналітика.

Крім цього, обов’язково має бути проаналізована модель компетентностей менеджера 3 персоналу, яка використовується HRCI - провідною організацією з сертифікації в сфері управління людьми, яка встановлює стандарти відповідності, досконалості та досвіду для менеджменту персоналу [20]. Протягом майже 30 років іх дослідження HR-компетентностей емпірично визначало компетентності HR-фахівців та те, як вони впливають на ефективність. Згідно цих досліджень було виділено на дев’ять компетентностей HRCI, які потрібні сучасному менеджеру з персоналу для досягнення успіху, з яких три дослідники визначили як основні рушії. Ці компетенції керують стратегічними ініціативами, розміщують HR у місці довіри до організації та полегшують здатність HR керуватися пріоритетами, що конкурують: здатність стратегічно позиціонувати бізнес, щоб завоювати його ринок; здатність будувати відносини довіри, маючи активну точку зору; здатність управляти напругою, притаманною бізнесу. Крім цього, дослідники визначили три категорії HR-компетентностей як можливості організації, які допомагають позиціонувати HR для досягнення стратегічної цінності: здатність здійснити зміни та керувати організаційною культурою; здатність управляти потоком талантів, розвиваючи людей та лідерів, керуючи індивідуальними показниками та формуючи технічний талант; здатність управляти добробутом працівників за допомогою фінансових та нефінансових винагород. Ці три компетентності дозволяють службам персоналу використовувати силу власного персоналу для просування організації вперед. Управління культурою, людським капіталом та стимулами $є$ важливими для розвитку загально організаційних можливостей. Нарешті, три HR-компетентності були визначені як засоби, що забезпечують надання послуг, зосереджених на управлінні тактичними або основними елементами управління персоналом: здатність використовувати технології та соціальні медіа для стимулювання та створення високопродуктивних організацій; здатність використовувати аналітику для вдосконалення процесу прийняття рішень; здатність управляти процесами, пов'язаними із дотриманням вимог, дотримуючись нормативних вимог. Ці дев'ять компетентностей не охоплюють весь спектр сфери управління персоналом, але вони є міцною основою для успіху.

Деталізація та сутності, дескрипторів кожної компетентності менеджера з персоналу на основі [6; 20; 26], ïх порівняльний аналіз на основі зіставлення та проведення аналогії кожної з розглянутих міжнародних моделей і загальноприйнятими в Україні поділом на загальні і спеціальні (професійні) компетентності, дозволив нам узагальнити і структурувати їх непорушуючи логіки в першоджерелахі, водночас, зробивши адаптивними до вітчизняної практики, а тому, на нашу думку, більш зручними для використання при аналізі ринку праці. Результати адаптивних міжнародних моделей наведені на Рисунку 1.

Результати проведеного нами дослідження показали, що моделі HR компетентностей, представлені SHRM, CIPD та HRCI, мають багато схожих ознак, але найбільше представлених компетентностей міститься в моделі SHRM та CIPD, на противагу в HRCI ми спостерігаємо менший хоча й змістовний 
вибір компетентностей для менеджерів 3 персоналу. Такі компетентності, як ділова хватка, навчання, управління талантами, розвиток персоналу, управління ризиками - найчастіше спостерігаються, як спільні між зазначеними моделями компетентностей менеджера з персоналу. Проте сфера менеджменту персоналу досить широка і багатогранна, тому варто розуміти, що окремі представлених компетентностей в різній мірі будуть важливі досліджуваної посади менеджера з персоналу. Крім того, вони матимуть різний рівень затребуваності на ринку праці України через відмінну від Сполучених штатів Америки та Великобританії структуру попиту на знання, вміння та навички в сегменту «Менеджменту персоналу».

Аналіз попиту на компетентності на ринку праці України в сегменті «Менеджменту персоналу» будо здійснено на основі дослідження оголошень про вакансії на основних порталах залучення кандидатів (rabota.ua, work.ua). Генеральна сукупність для аналізу представлена оголошеннями про вакансії в сегменті «Менеджмент персоналу» на основних порталах залучення кандидатів - rabota.ua та work.ua протягом січня-березня 2021 року. За досліджуваний період у середньомісячний обсяг попиту в даному сегменті становив на rabota.ua 934 оголошення про вакансії та на work.ua 1.556 оголошень про вакансії. Зважаючи на можливість дублювання (паралельного публікування компаніями оголошень про вакансії на обох порталах) до розрахунку було взято середній показник - 1.245 оголошень про вакансії.

Для обгрунтування вибірки біло почергово застосовано наступні методи визначення їі обсягу: довільний метод розрахунку, за якого обсяг вибірки визначається на рівні 5-10\% від генеральної сукупності - відповідно до генеральної сукупності обсяг вибірки має становити від 62 до 124 вакансій; статистичний метод розрахунку, за якого обсяг вибірки розраховується на основі спеціальних статистичних формул (1) [25]:

$n=\frac{t^{2} \cdot S^{2} \cdot N}{\Delta_{x}^{2} \cdot N+t^{2} \cdot S^{2}}$

де $n$ - обсяг вибірки; $N$ - обсяг генеральної сукупності; $t$ - нормоване відхилення, яке визначається виходячи з обраного рівня довірливості; $S$ - знайдена варіація для вибірки, $w$ - показник частки; $S^{2}-$ дисперсія випадкової величини, $\Delta$ - припустима межа похибки.

Розрахований за формулою (1) обсяг вибірки для генеральної сукупності 1.245 вакансій; нормованого відхилення 1.96 (рівень довірливості - довірчий інтервал 95\%); допустимої межі похибки висновків - до $10 \%$; варіації для вибірки за відсутності статистичної інформації прийнято на рівні 0.5 , оскільки це дає максимальну дисперсію (отриманий таким чином показник для обсягу вибірки буде завищеним, що дає додаткову надійність результатів) становитиме:

$n=\frac{1.96^{2} \cdot 0.5^{2} \cdot 1.245}{0.1_{x}^{2} \cdot 1.245+1.96^{2} \cdot 0.5^{2}}=83$ оголошення про вакансії.

Проведені розрахунки дають нам підстави стверджувати репрезентативність проведених нами досліджень в обсязі 100 оголошень про вакансії великих і середніх компаній України.

Систематизація та узагальнення результатів дослідження вимог до компетентностей менеджера 3 персоналу було здійснено на основі поділу їх на загальні компетентності та професійні компетентності, серед яких окремо було виділено управлінські компетентності та спеціальні функціональні компетентності, які відображають специфіку діяльності в напрямі функціональної сфери «менеджмент персоналу». Крім того, було визначено, три півні затребуваності компетентностей менеджера з персоналу на ринку праці: низький - при частоті попиту на компетентність нижче $30 \%$, середній - від $30 \%$ до $60 \%$ та високий - більше $60 \%$.

Результати аналізу попиту на загальні компетентності (далі - ЗК) на ринку праці України в сегменті «Менеджменту персоналу» представлено у Таблиці 1. 


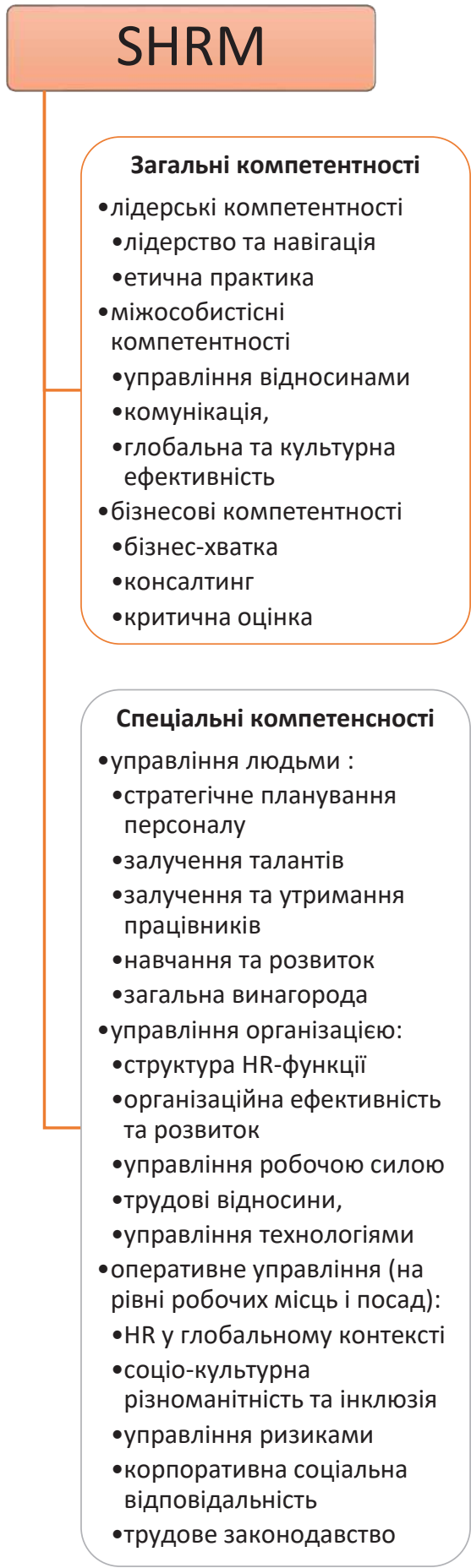

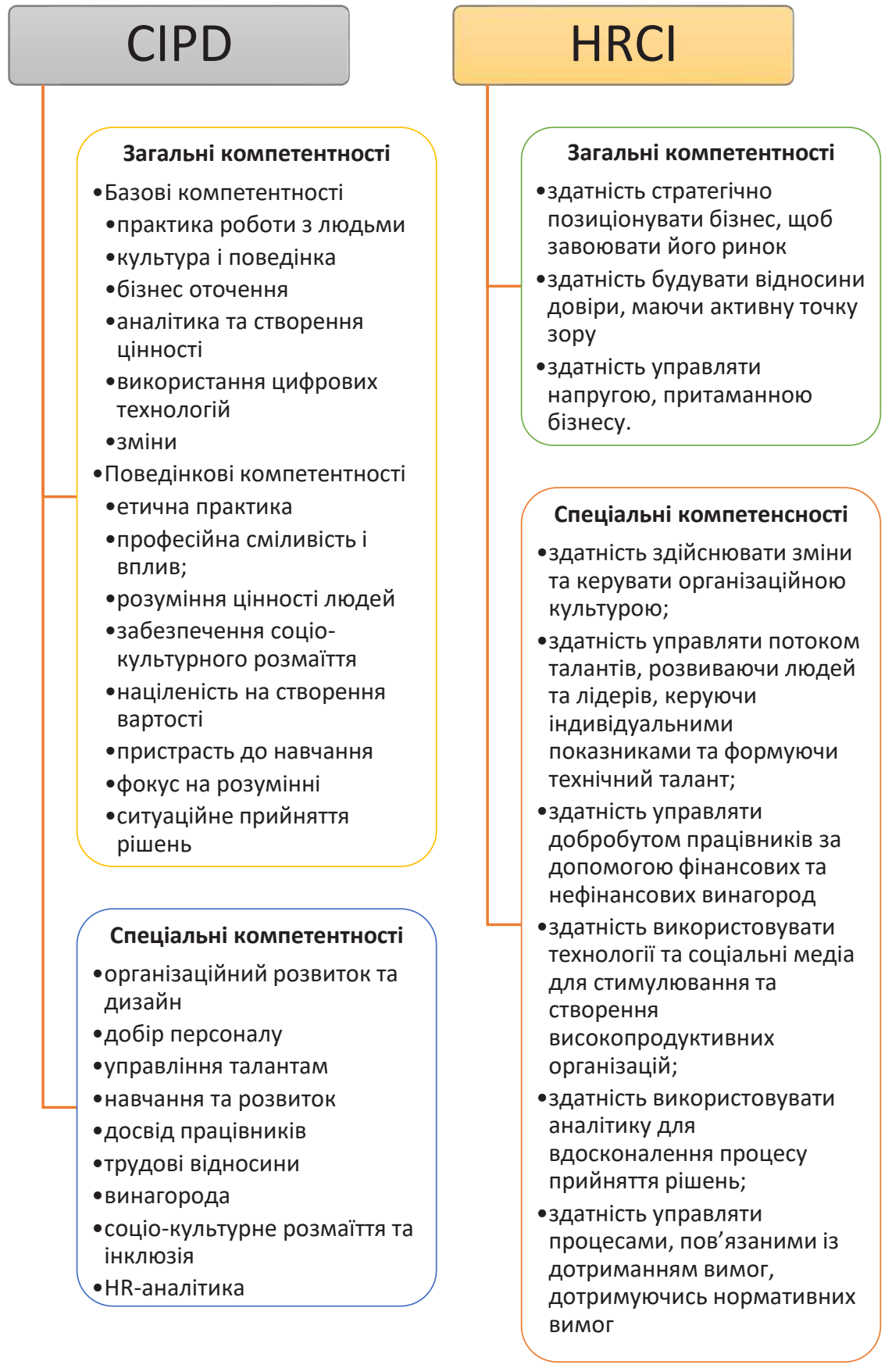

Джерело: Авторська розробка на основі узагальнення та структуризації [6; 20; 24; 26].

Рисунок 1. Актуальні компетентності менеджера з персоналу згідно основних міжнародних моделей HR компетентностей 
Таблиця 1. Аналіз попиту на загальні компетентності менеджера з персоналу на ринку праці України в сегменті «Менеджменту персоналу» у січні - березні 2021 року

Джерело: Розроблено авторами.

\begin{tabular}{|c|c|c|c|}
\hline Компетентність & $\begin{array}{c}\text { Умовне } \\
\text { позначення }\end{array}$ & $\begin{array}{l}\text { Частота попиту на } \\
\text { ринку праці }\end{array}$ & $\begin{array}{c}\text { Рівень вагомості } \\
\text { у моделі } \\
\text { компетентностей }\end{array}$ \\
\hline Здатність відповідально ставитися до роботи & ЗК01 & $54 \%$ & 0.042 \\
\hline Навички впевненого використання цифроових технологій & Зк02 & $44 \%$ & 0.035 \\
\hline Здатність до безперервного навчання & ЗК03 & $32 \%$ & 0.025 \\
\hline Здатність до ініціативного виконання завдань & ЗК04 & $32 \%$ & 0.025 \\
\hline Навички ведення переговорів & Зк05 & $26 \%$ & 0.020 \\
\hline $\begin{array}{l}\text { Здатність успішно здійснювати професійну діяльність у } \\
\text { стресогенних умовах }\end{array}$ & ЗК06 & $24 \%$ & 0.019 \\
\hline Здатність оперативно виконувати завдання & ЗК07 & $18 \%$ & 0.014 \\
\hline $\begin{array}{l}\text { Здатність швидко і легко адаптуватися та діяти в новій } \\
\text { ситуації }\end{array}$ & ЗК08 & $14 \%$ & 0.011 \\
\hline Здатність спілкуватися англійською мовою & ЗК09 & $12 \%$ & 0.009 \\
\hline $\begin{array}{l}\text { Здатність чітко та своєчасно виконувати роботу з } \\
\text { дотриманням певних правил і умов }\end{array}$ & ЗК10 & $2 \%$ & 0.002 \\
\hline
\end{tabular}

Сучасні компанії України серед загальних компетентностей менеджера з персоналу найбільше цінують здатність відповідального ставлення до роботи (вказано у $54 \%$ оголошень про вакансії); навички впевненого використання цифрових технологій - 44\%, здатність до безперервного навчання та здатність до ініціативного виконання завдань - по 32\% відповідно. Такий зріз пояснюється, на нашу думку, особливостями реалізації трудових процесів менеджерів 3 персоналу в сучасних «нових нормальних» умовах пандемічної реальності, яка передбачає підвищений рівень відповідальності та зростання вимог до цифрової компетентності, які стають обов'язковою умовою ефективного виконання обов'язків при дистанційній організації трудової діяльності. Здатність вчитися і оволодівати сучасними знаннями, застосовувати знання у практичних ситуаціях, здатність до саморозвитку та навчання впродовж життя - це ті компетентності які актуалізувалися сучасними трендами розвитку сфери менеджменту персоналу, пов'язаними із постійним зростанням вимог до виконання роботи. Так, згідно з дослідженнями Deloitte, керівники сучасних компаній серйозно занепокоєні впливом цифрових технологій, таких як роботизація та штучний інтелект на зміну характеру роботи та способи підготовки персоналу до її виконання. Зокрема, у зазначеному дослідженні до найважливіших питань менеджменту персоналу, які мають бути нагально вирішені визначено: перехід до бізнес-процесів майбутнього (28\%), необхідність реорганізації робочого середовища (25\%) і перенавчання працівників (24\%) [8]. Окрім результатів проведених нами досліджень вагомість здатності до ініціативного виконання робіт в моделі компетентностей менеджера з персоналу підтверджує практика менеджменту персоналу важливість ініціативності, вміння управляти процесами в організації, а також брати в них участь для посад в сфері менеджменту персоналу, особливо вищого рівня [10]. Очевидно, що ці чотири загальних компетентності все ж не володіють досить високим рівнем вагомості в моделі затребуваних на українському ринку праці компетентностей менеджера з персоналу проте становлять майже $2 / 3$ від усіх актуальних загальних компетентностей в сегменті «Менеджменту персоналу» (Рисунок 2).

Професійні компетентності на ринку праці користуються значно вищим попитом. Результати аналізу попиту на управлінські компетентності (далі - УК) та спеціальні функціональні компетентності (далі СК ) на ринку праці України в сегменті «Менеджменту персоналу» представлено у Таблицях 2-3. 


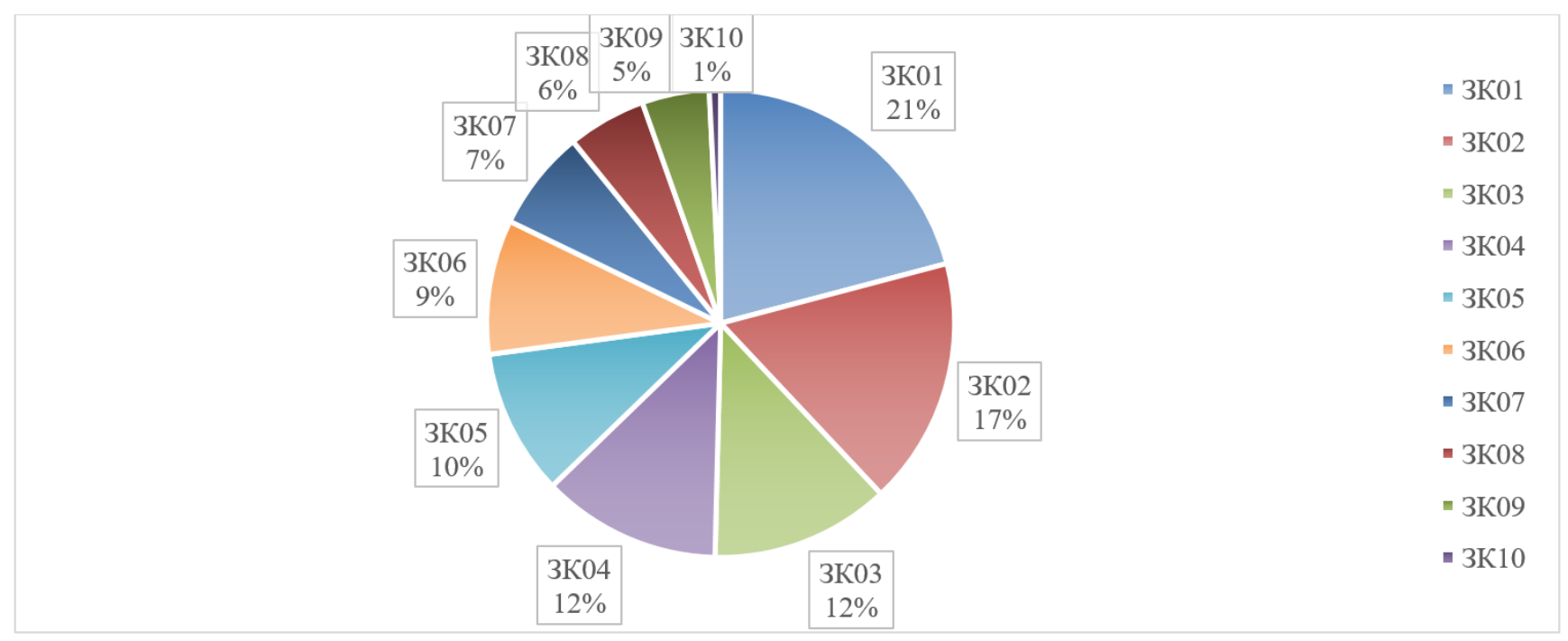

Джерело: Розраховано авторами

Рисунок 2. Структура попиту на загальні HR компетентності на ринку праці України у січніберезні 2021 року

Таблиця 2. Аналіз попиту на управлінські компетентності менеджера з персоналу на ринку праці України в сегменті «Менеджменту персоналу» у січні - березні 2021 року

Джерело: Розроблено авторами.

\begin{tabular}{|c|c|c|c|}
\hline Компетентність & $\begin{array}{c}\text { Умовне } \\
\text { позначення }\end{array}$ & $\begin{array}{l}\text { Частота попиту на } \\
\text { ринку праці }\end{array}$ & $\begin{array}{c}\text { Рівень вагомості } \\
\text { у моделі } \\
\text { компетентностей }\end{array}$ \\
\hline Здатність до ефективної комунікації в процесі управління & УК01 & $54 \%$ & 0.042 \\
\hline $\begin{array}{l}\text { Здатність досягати передбачуваних результатів при } \\
\text { виконанні професійних завдань }\end{array}$ & УКО2 & $50 \%$ & 0.039 \\
\hline Аналітичне мислення та здатність аналізувати & УКОЗ & $40 \%$ & 0.031 \\
\hline Здатність працювати в режимі багатозадачності & УКО4 & $34 \%$ & 0.027 \\
\hline Здатність до самомотивації та мотивації підлеглих & УКо5 & $22 \%$ & 0.017 \\
\hline $\begin{array}{l}\text { Здатність концентруватися на виконанні професійних } \\
\text { завдань. вчиняти дії. не відволікаючись на сторонні справи }\end{array}$ & Уко6 & $22 \%$ & 0.017 \\
\hline Здатність до ефективного самоменеджменту & УКо7 & $18 \%$ & 0.014 \\
\hline Здатність працювати в команді & УКов & $16 \%$ & 0.013 \\
\hline Вміння визначати пріоритетність роботи & УКо9 & $12 \%$ & 0.009 \\
\hline $\begin{array}{l}\text { Навички по роботі з внутрішніми клієнтами (B2B) та } \\
\text { клієнто-орієнтованість }\end{array}$ & УК10 & $10 \%$ & 0.008 \\
\hline $\begin{array}{l}\text { Здатність формувати лідерські якості та демонструвати їх в } \\
\text { процесі управління людьми }\end{array}$ & УК11 & $8 \%$ & 0.006 \\
\hline $\begin{array}{l}\text { Здатність використовувати знання економічних процесів в } \\
\text { професійній діяльності }\end{array}$ & УК12 & $4 \%$ & 0.003 \\
\hline $\begin{array}{l}\text { Здатність до швидкого вирішення проблем та прийняття } \\
\text { рішень }\end{array}$ & Ук13 & $4 \%$ & 0.003 \\
\hline
\end{tabular}

Як проілюстровано у Таблиці 2, рівень затребуваності на ринку праці України окремих управлінських компетентностей для менеджера з персоналу становить більше $50 \%$ Зокрема, частка попиту на ринку праці на: здатність до ефективної комунікації в процесі управління становить 54\% і в оголошеннях про вакансію описується дескрипторами здійснювати двосторонній обмін інформацією з метою розуміння, включно з вербальним, невербальним та письмовим спілкуванням для вирішення професійних завдань; спілкуватися державною мовою як усно, так і письмово; створювати ефективні комунікації в колективі; 


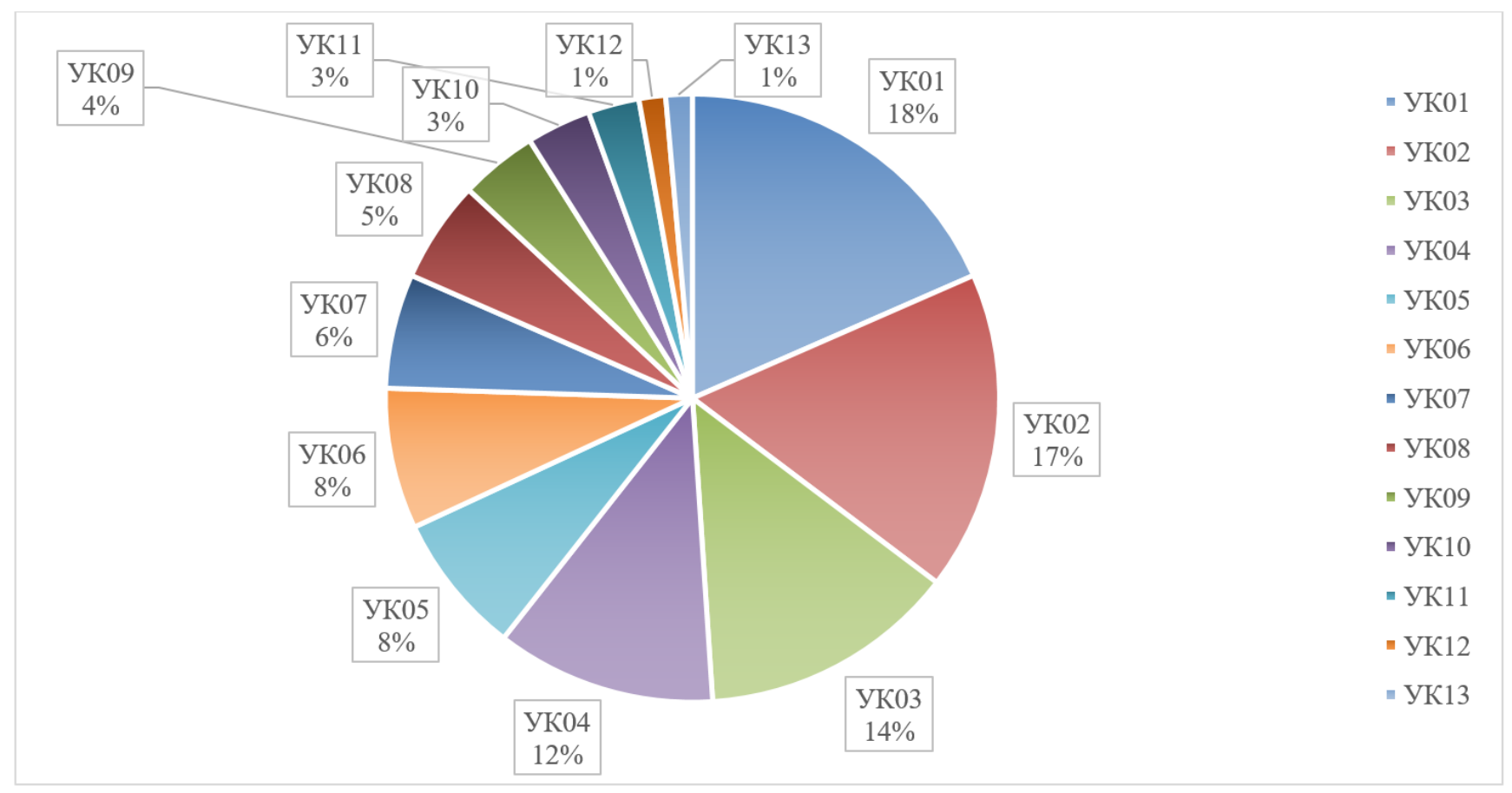

Джерело: Розраховано авторами

\section{Рисунок 3. Структура попиту на управлінські HR компетентності на ринку праці України у січні-березні 2021 року}

та здатність досягати передбачуваних результатів при виконанні професійних завдань - 50\%. Крім цього, досить високим $€$ попит на інші управлінські компетентності, а саме: $40 \%$ - аналітичне мислення та здатність аналізувати, яке деталізується як здатність логічно міркувати, знаходити аргументи, ставити під сумнів власні та інші судження, виявляти сильні та слабкі сторони різних підходів до вирішення проблеми; аналізувати й структурувати проблеми організації, формувати обгрунтовані рішення; аналізувати результати діяльності організації, зіставляти їх з факторами впливу зовнішнього та внутрішнього середовища; та 34\% - здатність працювати в режимі багатозадачності, виконувати декілька завдань одночасно. В цілому, описані чотири управлінських компетентності мають високий та середній рівень затребуваності та характеризуються рівнем вагомості від 0.042 до 0.027 відповідно. У моделі затребуваних на українському ринку праці компетентностей менеджера з персоналу вони становлять $61 \%$ від усіх актуальних управлінських компетентностей в сегменті «Менеджменту персоналу» (Рисунок 3).

Природнім $€$ найвищий рівень затребуваності спеціальних функціональних компетентностей менеджера з персоналу на ринку праці України (Таблиця 3). Серед спеціальних функціональних компетентностей менеджера 3 персоналу 6 характеризуються високим рівнем затребуваності, а 2 середнім. Зокрема, конкурентоспроможність менеджера з персоналу на ринку праці України, на сьогодні визначається на 96\% здатністю організовувати та реалізовувати процеси добору персоналу, на $84 \%$ здатністю здійснювати пошук кандидатів на вакантні посади та робочі місця, на 82\% здатність працювати з персоналом та реалізовувати процеси менеджменту персоналу; на 70\% здатністю організовувати та реалізовувати процеси адаптації персоналу, на 60\% здатністю оцінювати кандидатів на вакантну посаду у, забезпечувати їх якість добору. Важливими є також здатність ведення кадрового документообігу та документаційного супроводу HR процесів (34\%) та здатність планувати та формувати кадровий резерв (30\%). 
Таблиця 3. Аналіз попиту на спеціальні функціональні компетентності менеджера 3 персоналу на ринку праці України в сегменті «Менеджменту персоналу» у січні - березні 2021 року

Джерело: Розроблено авторами

\begin{tabular}{|c|c|c|c|}
\hline Компетентність & $\begin{array}{c}\text { Умовне } \\
\text { позначення }\end{array}$ & $\begin{array}{l}\text { Частота попиту } \\
\text { на ринку праці }\end{array}$ & $\begin{array}{l}\text { Рівень вагомості } \\
\text { у моделі } \\
\text { компетентностей }\end{array}$ \\
\hline $\begin{array}{l}\text { Здатність організовувати та реалізовувати процеси добору } \\
\text { персоналу }\end{array}$ & СК01 & $96 \%$ & 0.075 \\
\hline $\begin{array}{l}\text { Здатність здійснювати пошук кандидатів на вакантні посади та } \\
\text { робочі місця }\end{array}$ & СК02 & $84 \%$ & 0.066 \\
\hline $\begin{array}{l}\text { Здатність працювати з персоналом та реалізовувати процеси } \\
\text { менеджменту персоналу }\end{array}$ & СК03 & $82 \%$ & 0.064 \\
\hline $\begin{array}{l}\text { Здатність організовувати та реалізовувати процеси адаптації } \\
\text { персоналу }\end{array}$ & СК05 & $70 \%$ & 0.055 \\
\hline $\begin{array}{l}\text { Здатність оцінювати кандидатів на вакантну посаду та } \\
\text { забезпечувати їх якість добору }\end{array}$ & СК06 & $60 \%$ & 0.047 \\
\hline $\begin{array}{l}\text { Здатність ведення кадрового документообігу та } \\
\text { документаційного супроводу HR процесів }\end{array}$ & СК07 & $34 \%$ & 0.027 \\
\hline Здатність планувати та формувати кадровий резерв & СК08 & $30 \%$ & 0.024 \\
\hline Здатність мотивувати персонал & СКО9 & $28 \%$ & 0.022 \\
\hline Здатність складати та подавати кадрову звітність & СК10 & $28 \%$ & 0.022 \\
\hline $\begin{array}{l}\text { Здатність організовувати та реалізовувати процеси навчання } \\
\text { та розвитку персоналу }\end{array}$ & СК11 & $24 \%$ & 0.019 \\
\hline Здатність використовувати сучасні технології рекрутингу & СК12 & $24 \%$ & 0.019 \\
\hline Здатність планувати та організовувати корпоративні заходи & СК13 & $22 \%$ & 0.017 \\
\hline $\begin{array}{l}\text { Здатність використовувати знання трудового законодавства в } \\
\text { професійній діяльності }\end{array}$ & СК14 & $18 \%$ & 0.014 \\
\hline Здатність аналізувати ринок праці & СК15 & $16 \%$ & 0.013 \\
\hline $\begin{array}{l}\text { Здатність працювати з великими масивами професійних даних } \\
\text { (big data), в тому числі в цифровому середовищі }\end{array}$ & СК16 & $10 \%$ & 0.008 \\
\hline $\begin{array}{l}\text { Здатність складати та контролювати бюджету витрат на } \\
\text { персонал }\end{array}$ & СК17 & $6 \%$ & 0.005 \\
\hline $\begin{array}{l}\text { Здатність розробляти стратегію і політику менеджменту } \\
\text { персоналу та планувати заходи їх реалізації відповідно до } \\
\text { бізнес-стратегії }\end{array}$ & СК18 & $4 \%$ & 0.003 \\
\hline $\begin{array}{l}\text { 3датність досліджувати, формувати та розвивати позитивний } \\
\text { бренд роботодавця на внутрішньому на зовнішньому ринках } \\
\text { праці }\end{array}$ & СК19 & $4 \%$ & 0.003 \\
\hline $\begin{array}{l}\text { Здатність розробляти програми навчання для різних категорій } \\
\text { персоналу для працівників }\end{array}$ & СК20 & $4 \%$ & 0.003 \\
\hline Здатність оцінювати задоволеність персоналу & СК21 & $2 \%$ & 0.002 \\
\hline
\end{tabular}

В цілому, описані спеціальні компетентності (СК01 - СК06) характеризуються рівнем вагомості від 0.075 до 0.024 відповідно. У моделі затребуваних на українському ринку праці компетентностей менеджера 3 персоналу вони становлять більше 70\% від усіх актуальних спеціальних функціональних компетентностей в сегменті «Менеджменту персоналу» (Рисунок 4).

Модель HR-компетентностей, затребуваних на ринку праці України, відображена на Рисунку 5. Очевидним э той факт, що вона кардинально відрізняється від традиційних міжнародних моделей. На нашу думку, основним поясненням такої диференціації $\epsilon$, насамперед, особливості розвитку підходів щодо управління людьми, які історично склалися в Україні. Вітчизняна практика і наукова думка в цій сфері відчула на собі вплив численних чинників суспільно-історичного, політичного, економічного та соціального характеру, деталізація яких потребує поглибленого вивчення. Другим вагомим аргументом для обгрунтування $€$ особливості функціонування вітчизняного ринку праці в умовах пандемії COVID-19. 


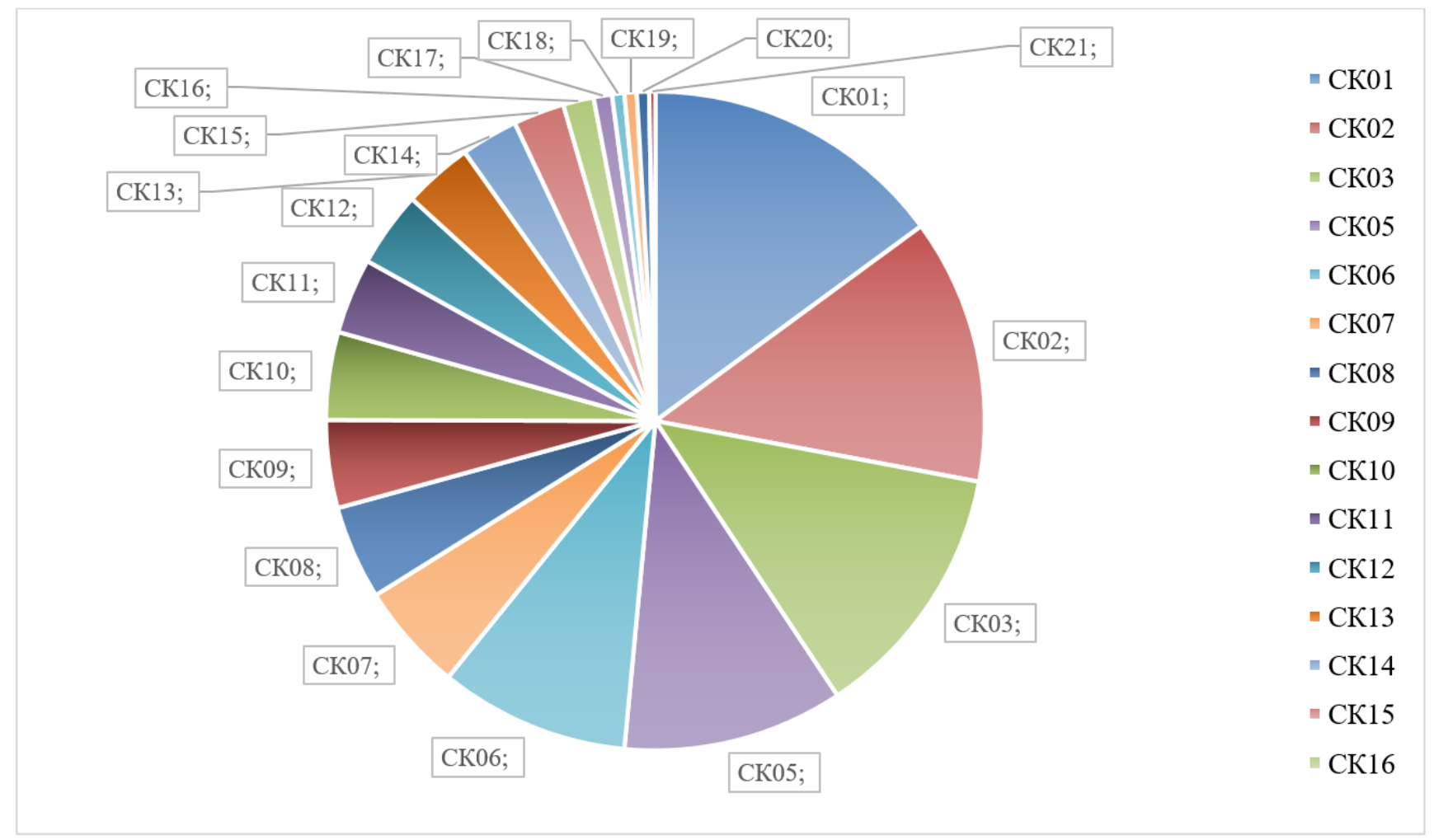

Джерело: Розраховано авторами.

Рисунок 4. Структура попиту на спеціальні HR компетентності на ринку праці України у січні-березні 2021 року

\section{5. ОБГОВОРЕННЯ}

Зараз лише лінивий не робить прогнози щодо трансляції сформованих підчас пандемії змін у майбутнє. Існує чимало прогнозів розвитку світу у постпандемічний період, які мають на меті виділити ті зміни, які залишаться з нами і стануть нормою. В цьому контексті сформувався цілий напрям футуристичнопрогностичних досліджень, які описують так звану «new normal» для різних сфер діяльності людини. Тобто це поточна ситуація, соціальні звичаї тощо, що відрізняється від того, що було раніше або пережито, але, як очікується, стане звичним або типовим. Не виключення $є$ і сфера управління людьми в бізнесі, для якої ці питання є особливо актуальними.

Пандемія COVID-19 приймає трагічні наслідки з точки зору здоров'я людей та громадського здоров'я, a також спричиняє масштабні зриви бізнесу, в результаті чого деякі підприємства повністю закриваються. На відміну від них, інші змушені швидко розширювати сервісні групи та нарощувати виробництво, щоб задовольнити підвищені вимоги. В той же час у багатьох компаніях практично за одну ніч всі робочі місця стали віддаленими. Пандемія змінила світову економіку та бізнес, а людина $\epsilon$ їх основою. Усі необхідні зараз організаціям зміни для відновлення діяльності в своїй основі мають людину. Тому роль управління людьми суттєво зростає. Актуалізуються питання: безпеки персоналу і не тільки фізичної на робочому місці, а й соціальної, психологічної, інформаційної - питання яких особливо загострилося внаслідок COVID-19; організації трудової діяльності в умовах віддаленого доступу до робочого місця, трансформація робочих місць та переродження їх у цифрові поставить нові вимоги до численних процесій менеджменту персоналу від нових способів організації щоденної діяльності персоналу до концептуального перетворення підходів до управління корпоративною культурою; соціальної складової управління людьми в організації для нівелювання тих негативних соціальних наслідків, які виникають у зв’язку із відсутністю живого спілкування, страхом перед втратою здоров’я, життя тощо. 




Джерело: Розроблено авторами.

\section{Рисунок 5. Модель HR-компетентностей відповідно до попиту на ринку праці України}

В цілому, сучасна ситуація спричинила виникнення потреби у адаптації та стійкості сучасного працівника, пришвидшила перехід до нової цифрової економіки та підкреслили важливість менеджменту персоналу у новій нормальній реальності. Нова нормальність для менеджменту персоналу полягає в тому, що сучасний фахівець з управління людьми відіграє ключову роль у підтримці безперервності бізнесу, керуванні постійними зусиллями щодо трансформації та підтримці прийнятих кадрових рішень. Найуспішніші HR-команди визначають нову норму з найкращими практиками, що забезпечують обгрунтоване прийняття рішень та організаційну спритність. Тому на ринку праці України актуалізувалися HR-компетентності, які дозволять сучасному менеджеру з персоналу реалізовувати процеси щодо підтримання безперервності бізнесу в умовах кризи. Це, по-перше, введення заходів щодо охорони здоров’я та безпеки працівників, таких як протоколи соціального дистанціювання для контролю за розповсюдженням вірусу, політика дистанційної роботи та організація віддаленого доступ до робочого місця. По-друге, безперервність діяльності передбачає успішне їі відновлення через впровадження заходів та рішень для пом'якшення впливу спалаху на здоров'я та добробут працівників та дії щодо нормалізації попиту та пропозиції при різкій зміні умов діяльності. I, по-трете, це формування тієї нової норми, яка дозволить пристосуватись до обставин, як того вимагають умови. 
Нова норма для управління людьми в організаціях буде формуватися, на нашу думку, на основі тих бізнес-процесів, які сприятимуть необхідним трансформаціям бізнесу. Тенденції в організаційних перетвореннях, до спалаху пандемії, характеризувалися націленістю на підвищення спритності, гнучкості менеджменту персоналу, цифровізацією основних його процесів для отримання конкурентних переваг на ринку праці. Ще до пандемії, щоб конкурувати за висококваліфікованих працівників «міленіалів» та «покоління Z» впроваджувались інновації пов’язані з трансформацією корпоративної культури, впровадженням гнучких графіків, дистанційної зайнятості, нових технологій для організації віддаленого робочого місця. Але зараз протоколи соціальної дистанції пандемії надали цим ініціативам нової актуальності й вимагають від організацій перегляду звичайних режимів організації трудової діяльності. У цих умовах необхідними стають HR-компетентності, які формують здатність менеджера 3 персоналу активізувати свою діяльність і демонструвати свою цінність як бізнес-партнера через передачу даних та досвіду, напрацювання способів динамічного та спритного врегулювання кадрової ситуації. Зокрема, це стосується оптимізації ресурсів, необхідних для підтримки продуктивності віддаленої робочої сили, включаючи цифрові ресурси, що, своєю чергою, вимагає високого рівня розвитку цифрових та аналітичних компетентностей, вміння працювати з великими масивами даних та приймати швидкі рішення. В таких умовах, на першу роль виходять стратегічні HR-компетентності, які дозволять ефективно реалізовувати функцію планування, яка 6 поєднувала захист працівника та максимізувала продуктивність праці в складних умовах. Найуспішніші менеджери з персоналу формують критичні навички та компетентності, зберігаючи зайнятість та захист працівників.

Складаючи коротко- чи довготермінові антикризові плани менеджер з персоналу має мати навички оперативновизначити критичніпозиціїта ключових працівників:працівники, якімають бути доступними за будь-яких обставин: при тимчасовому призупиненні діяльності організації - потрібно визначити працівників, яких можуть тимчасово відсторонити від роботи; при розширеному призупиненні працівників, яких можуть відсторонити на тривалий або невизначений час тощо. Тут головне оцінити, чи достатня чисельність працівників для виконання основних обов'язків у міру розвитку умов, а якщо ні, то вжити заходів, таких як перехресне навчання, сертифікація чи пошук тимчасового персоналу чи персоналу за контрактом, який би служив кадровим резервом. Саме в цьому полягає здатність HRкоманди, в будь яких непередбачуваних умовах і в умовах кризи забезпечувати роботу компанії.

Сучасний менеджер з персоналу в пандемічний і постпандемічний період має докладати значних зусиль для підтримання безперервності бізнесу, стимулювання трансформації та забезпечення того, щоб потрібні люди знаходились у правильних місцях, щоб допомогти своїй компанії виконати свою місію, незалежно від того, чи знаходиться це місце вдома на віддаленій роботі або на в офісі «на передовій» для надання основних послуг. Це складний набір завдань навіть за звичайних умов, і надзвичайна ситуація у галузі охорони здоров'я додає новим вимірам та актуальності ролі HR. Сучасні можливості HR-аналітики та візуалізації можуть швидко дати командам HR уявлення про їх поточний стан та резервні ресурси та надати інструменти для управління кризою.

\section{ВИСНОВКИ}

Результати проведеного дослідження щодо узагальнення досягнень сучасної наукової думки та міжнародного досвіду формування моделей компетентностей менеджера 3 персоналу, а також сучасних тенденцій розвитку менеджменту персоналу як сфери професійної діяльності підтверджують необхідність розроблення нової моделі HR компетентностей. Порівняльний аналіз міжнародних моделей компетентності, які використовують провідні світові сертифікаційні інститути та організації в сфері менеджменту персоналу, дозволив нам зробити висновки про їх деяку невідповідність, але, водночас виявити спільні риси та провести їх адаптацію до традиційних вітчизняних кластерів компетеностей. Цей підхід будо покладено в основі аналізу попиту на HR-компетентності на українському ринку праці в сегменті «Менеджменту персоналу». Отримані результати засвідчили унікальність затребуваних в Україні HR-компетентностей від прийнятого на міжнародному рівні узагальненого стандарту. Основними причинами такої диференціація виділено особливості розвитку підходів щодо управління людьми, які історично склалися в Україні, та особливості функціонування вітчизняного ринку праці в умовах пандемії COVID-19. 
В зв’язку з чим можна зробити висновки, що в Україні дійсно потрібне розроблення уніфікованої моделі HR-компетентностей, у якій би будо адаптовано міжнародні практики у цьому напрямі, враховані тенденції розвитку ринку праці та трансформацію функції менеджменту персоналу в нових нормальних умовах пандемічної та постпандемічної реальності. Така модель може стати методологічною оновою формування проекту професійного стандарту менеджера з персоналу і створити сприятливі передумови для розроблення проекту та затвердження на державному рівні Професійного стандарту з управління персоналом. Подальший розвиток наукових та прикладний досліджень цій сфері позитивно вплине на якість реалізації функції менеджменту персоналу та зробить можливим переходу на новий рівень якості у підготовці профільних фахівців в системі вищої освіти України, розроблення нових освітніх стандартів та освітніх програм в сфері менеджменту персоналу, а також запровадження національної системи сертифікації для професіоналів з управління персоналом з метою оцінювання якості кадрового забезпечення реалізації функції менеджменту персоналу в Україні.

\section{AUTHORS CONTRIBUTIONS}

Conceptualization: Oksana Kravchuk.

Data curation: Oksana Kravchuk, Tetyana Bidna.

Formal Analysis: Oksana Kravchuk.

Funding acquisition: Oksana Kravchuk, Iryna Varis.

Investigation: Oksana Kravchuk, Tetyana Bidna.

Methodology: Oksana Kravchuk.

Project administration: Oksana Kravchuk.

Resources: Oksana Kravchuk, Iryna Varis.

Software: Iryna Varis, Tetyana Bidna.

Supervision: Oksana Kravchuk.

Validation: Oksana Kravchuk, Iryna Varis, Tetyana Bidna.

Visualization: Iryna Varis.

Writing - original draft: Oksana Kravchuk, Tetyana Bidna.

Writing - review \& editing: Oksana Kravchuk, Iryna Varis.

\section{СПИСОК ЛІТЕРАТУРИ}

1. Alonso, A., Kurtessis, J., Schmidt, A., Strobel, K., \& Dickson, B. (2015). A Competency-Based Approach to Advancing HR. People \& Strategy, 38(4), 38-44. Retrieved from https://go.gale.com/ps/i.do?p=AONE\&u=anon $\sim 875 \mathrm{~d} 7$ ca6\&id=GALE|A552253053\&v=2.1\&it=r \&sid=googleScholar\&asid $=31951811$

2. Becker, S. (2019). The Global Movement for Human Resources Standards. HRExaminer. Retrieved from https://www.hrexaminer.com/ the-global-movement-for-human-resources-standards

3. Bersin, J. (2021). Insights on Work, Talent, Learning, Leadership, and HR Technology. Retrieved from https://joshbersin.com/page/7/

4. Burns, E., Smith, L., \& Ulrich, D. (2012). Competency Models with Impact: Research Findings from the Top companies for Leaders. The RBL Group White Paper Series. Retrieved from http://rblip.s3.amazonaws.com/Articles/Competency\%20Models\%20with\%20Impact. pdf

5. CHRP (2014). Certified Human Resources Professional Competency Framework. Retrieved from https://cphrbc.ca/wp-content/uploads/2014/09/CHRP-competency-framework.pdf

6. CIPD (2018). The Profession Map. Retrieved from https://peopleprofession.cipd.org/Images/full-standards-download-dec-2020_ tcm29-50113.pdf

7. Das Gupta, A. (2020). Strategic Human Resource Management: Formulating and Implementing HR Strategies for a Competitive Advantage (1st ed.). Productivity Press. https://doi.org/10.4324/9780429327728

8. Deloitte (2019). Bezperervne navchannia (2019 Deloitte Global Human Capital Trends) [Continuous learning (2019 Deloitte Global Human Capital Trends)]. Retrieved from https://www2.deloitte.com/content/dam/Deloitte/ua/Documents/human-capital/Deloitte-GlobalHuman-Capital-Trends-2019-7.pdf

9. European Commission (2018). Digital Education Action Plan (2021-2027). Resetting education and training for the digital age. Retrieved from https://ec.europa.eu/education/education-in-the-eu/digital-education-action-plan_en

10. Hlushenia, K. (2020). Kadrovyk nashoho chasu: khto takyi HR i yak nym staty [HR of our time: who is HR and how to become one]. (In Ukrainian). Retrieved from https://happymonday.ua/hto-takyj-hr-i-yak-nym-staty

11. Hodges, J., \& Crabtree, M. (2020). Reshaping HR: The Role of HR in Organizational Change (1st ed.) (240 p.). London: Routledge. https:// doi.org/10.4324/9781003123491 
12. Kolot, A. (2021). Social and labor reality - XXI: philosophy of formation, opportunities and challenges. Economy of Ukraine, 2, 3-31. https://doi.org/10.15407/economyukr.2021.02.003

13. Kravchuk, O. (2017). Analysis of the international practice of HR standardization. Socio-labor relations: theory and practice, 1, 142-158. (In Ukrainian). Retrieved from http://nbuv.gov.ua/UJRN/stvttp_2017_1_14

14. Kravchuk, O. (2018). HR-manager digital competency. Socio-labor relations: theory and practice, 1, 172-191. (In Ukrainian). Retrieved from http://nbuv.gov.ua/UJRN/stvttp_2018_1_19

15. Kravchuk, O. (2019). Personnel management professional standards: development and implementation in Ukraine. Social and labour relations: theory and practice, 9(1), 71-84. (In Ukrainian). http://dx.doi.org/10.21511/slrtp.9(1).2019.07

16. Loew, L. (2016) The Challenges and Benefits of Competency Management. Training Magazine. Retrieved from http://laciloew.com/news/ competency-management-challenges-and-benefits/

17. Lopushnyak, H., \& Mylyanyk, R. (2019). The influence of digital technologies on the formation of competencies of management personnel. Investytsii: praktyka ta dosvid - Investments: practice and experience, 24, 10-16. (In Ukrainian). https://doi.org/10.32702/23066814.2019.24.10

18. Mangaleswaran, T. (2015). Human Resource Competencies for Managing Challenges. Information and Knowledge Management, 5(9), 109-114. Retrieved from https://www.iiste.org/Journals/index.php/IKM/article/view/25599

19. McCartney, S., Murphy, C., \& Mccarthy, J. (2020). 21st century HR: a competency model for the emerging role of HR Analysts. Personnel Review. https://doi.org/10.1108/PR-12-2019-0670

20. Meginley, D. (2020). 9 Competencies for HR Excellence. HRCI. Retrieved from https://www.hrci.org/community/blogs-and-announcements/hr-leads-business-blog/hr-leads-business/2020/09/04/nine-competencies-for-hr-excellence-emerge

21. Petiukh, V., \& Voloboeva, I. (2019). Methodological principles of competencies evaluation for functional personnel at the bank. Efektyvna ekonomika - Efficient economy, 2. (In Ukrainian). https://doi.org/10.32702/2307-2105-2019.2.65

22. Petrova, I. (2013). Stratehichne upravlinnia liudskymy resursamy [Strategic Human Resource Management] (466 p.). Kyiv: KNEU. (In Ukrainian). Retrieved from https://library.krok.edu.ua/media/library/category/navchalni-posibniki/petrova_0003.pdf

23. Prabawati, I., \& AOktariyanda, T. (2018). Competency-based training model for human resource management and development in public sector. Journal of Physics: Conference Series, 953, 012157. https://doi.org/10.1088/1742-6596/953/1/012157

24. Pritula, M. (2020). Personalnaya karta razvitiya HR 40x40 [Personal HR development map 40x40]. Mike Pritula Academy. (In Russian). Retrieved from https://pritula.academy/hrmap?fbclid=IwAR2c7eITDgmB_vqgsPW45ch599us-6wrsG-NqF8VpL0oRHEhDT_qc3Zvq3E

25. Samborskyy, O., Slobodyanyuk, M., \& Shuvanova, O. (2017). Obhruntuvannia vyboru metodu formuvannia vybirky u doslidzhenniakh farmatsevtychnoho rynku [Rationale for the choice of sampling method in pharmaceutical market research] (27 p.). Kharkiv: National University of Pharmacy. (In Ukrainian)

26. SHRM (2018). The SHRM Body of Competency and Knowledge. Retrieved from https://www.shrm.org/certification/recertification/Documents/18-1534\%202019\%20BoCK_WEB.pdf

27. Stolyaruk, H. (2018). Professional standard for personnal manager: problems of development and using. Social and labour relations: theory and practice, 1, 312-322. (In Ukrainian). Retrieved from http://nbuv.gov.ua/UJRN/stvttp_2018_1_33

28. Storey, J., Ulrich, D., \& Wright, P. (2019). Strategic Human Resource Management (118 p.). London: Routledge, https://doi. org/10.4324/9780429490217

29. Ulrich, D. (2015). The rise of HR: Wisdom from 73 thought leaders (606 p.). Alexandria. HR Certification Institute.

30. Ulrich, D. (2020). HR's ever-emerging contribution. Strategic HR Review, 19(6), 251-257. https://doi.org/10.1108/SHR-08-2020-0071

31. Ulrich, D., \& Grochowski, J. (2018). Building a world class HR department. Strategic HR Review, 17(4), 181-185. https://doi.org/10.1108/ SHR-05-2018-0046

32. Ulrich, D., Younger, J., Brockbank, W., \& Ulrich, M. (2012). HR from the outside in: Six Competencies for the Future of Human Resources (336 p.). New York: McGraw-Hill Education.

33. Vasylyk, A., \& Kushnir, A. (2018). Ompetences of HR-specialist in the digital technologies era. Scientific Bulletin of KSU. Series «Economic Sciences», 28(2), 119-122. (In Ukrainian). Retrieved from http://ej.journal.kspu.edu/index.php/ej/article/view/48

34. Voloboeva, I. (2018). The mechanism of forming and implementation for competences model (methodological aspect). Social and labour relations: theory and practice, 1, 362-368. (In Ukrainian). Retrieved from https://ir.kneu.edu.ua/bitstream/handle/2010/24789/Voloboeva.pdf? sequence $=1 \&$ is Allowed $=y$ 